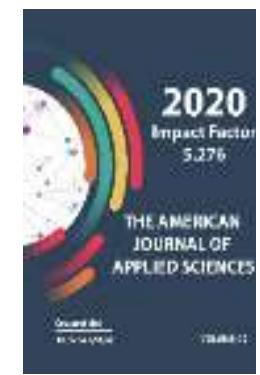

Journal Website: http://usajournalshub.c om/index,php/tajas

Copyright: Original content from this work may be used under the terms of the creative commons attributes 4.0 licence.

\section{Change Of Dimethyl Ether To Lower Alkenes In Boron And Phosphorus-Containing Catalysts}

\author{
Sh.Ch.Aslanov \\ Shurtan Gas Chemical Complex LLC, Uzbekistan \\ A.Q.Buxorov \\ Shurtan Gas Chemical Complex LLC, Uzbekistan
}

N. I. Fayzullaev

Doctor Of Technical Sciences, Professor, Samarkand State University, Uzbekistan

\title{
ABSTRACT
}

In this study, the possibility of the formation of lower olefins from dimethyl ether and methanol on catalysts containing Mg-Zn-Zr-B-HSZ and Mg-Zn-Zr-P-HSZ was studied, and the process was evaluated quantum chemically. According to the results obtained by IR-Fur spectroscopy, during the catalytic conversion of DME (dimethyl ether) on the surface of catalysts containing Mg-Zn-Zr-B-HSZ and Mg-Zn$\mathrm{Zr}$-P-HSZ ketenes at temperatures below $180{ }^{\circ} \mathrm{C}$ and oxonium intermediates at $320^{\circ} \mathrm{C}$ (intermediate). compounds) are confirmed by experimental spectra and theoretical quantum-chemical calculations. It was shown that the formation of olefins below DME occurs by the carbene mechanism at low temperatures and by the oxonylide mechanism at high temperatures.

\section{KEYWORDS}

Spectroscopy method, catalysts, experimental spectra, high siliceous zeolites, low-carbon, natural gas.

\section{ABBREVIATION}

DME-dimethyl ether; MTO - methanol to olefins; DTO - dimethyl ether to olefins; ZSM-5 - Zeolite Socony Mobil 5; HMDA - Hexamethylenediamine; Dimethyl ether-DME; HSZ - high siliceous zeolites; 


\section{INTRODUCTION}

At present, the world's annual demand for ethylene is 187 million tons, and this demand is growing by $4.5 \%$ per year [1-6]. Currently, about $5 \%$ of natural gas is used in the production of valuable products, the rest is used as fuel [7-9]. Ethylene is an important product of petrochemistry and gas chemistry and is used in the production of polyethene, polyvinyl chloride, polystyrene, alkylbenzenes, ethylene oxide, etc. [10-14]. Currently, there are 3 different ways of producing ethylene from natural blood. The first method is to obtain ethylene by synthesizing dimethyl ether or methanol, the second is by dimerization of methane, and the third is through methyl chloride. The chain of conversion of natural gas to ethylene with methanol consists of 3 stages:

- Synthesis - gas extraction:

$$
\begin{aligned}
& \mathrm{CH}_{4}+\mathrm{H}_{2} \mathrm{O} \leftrightarrow \mathrm{CO}+3 \mathrm{H}_{2}-206 \mathrm{~kJ} / \mathrm{mol}(1) \\
& \mathrm{CH}_{4}+\mathrm{CO}_{2} \leftrightarrow 2 \mathrm{CO}+2 \mathrm{H}_{2}-247 \mathrm{~kJ} / \mathrm{mol}(2) \\
& \mathrm{CH}_{4}+1 / 2 \mathrm{O}_{2} \leftrightarrow \mathrm{CO}+2 \mathrm{H}_{2}-36 \mathrm{~kJ} / \mathrm{mol} \text { (3) }
\end{aligned}
$$

- Extraction of methanol:

$$
\mathrm{CO}+\mathrm{CO}_{2}+5 \mathrm{H}_{2} \rightarrow 2 \mathrm{CH}_{3} \mathrm{OH}+\mathrm{H}_{2} \mathrm{O}
$$$$
\mathrm{T}=220-280^{\circ} \mathrm{C} ; \mathrm{P}=5-10 \mathrm{MPa} \text {, catalyst } \mathrm{Cu} / \mathrm{Zn} \text {. }
$$

- Conversion of methanol in the presence of a catalyst:

$$
n \mathrm{CH}_{3} \mathrm{OH} \rightarrow \mathrm{C}_{2} \mathrm{H}_{4}+\mathrm{C}_{3} \mathrm{H}_{6}+\mathrm{C}_{4} \mathrm{H}_{8}+\text { other hydrocarbons }+n \mathrm{H}_{2} \mathrm{O}
$$

The conversion rate of methane in synthesis gas extraction processes (1-3) is high, in reaction (3) oxygen is fully involved in the reaction. Methane homologues are completely transformed into $\mathrm{CO}$ and $\mathrm{H}_{2}$. The reaction mechanism of the MTO process (methanol to olefins-MTO) is fully studied in [15 - 18]. Catalysts of the MTO and DTO processes, their thermodynamics, kinetics and mechanism are described in [19-21]. Many catalysts have been tested in the MTO reaction [22 - 24]. Most often, zeolites of the ZSM- 5 type and molecular sieves of the SAPO type are tested in MTO reactions. In zeolites $\mathrm{HZSM}-5$ paraffin, aromatics, cycloparaffins and olefins $\mathrm{C}_{6+}$ are obtained. At present, in the reactions for converting methanol to olefins, ethylene and propylene are produced in a high yield on a modified aluminosilicate phosphate catalyst
SAPO-34 co-produced by UOP and Norsk Hydro.

Work aims to study the possibility of the formation of lower olefins from dimethyl ether and methanol in catalysts containing $\mathrm{Mg}-\mathrm{Zn}-\mathrm{Zr}$ B-HSZ and Mg-Zn-Zr-P-HSZ, as well as a quantum-chemical evaluation of the process.

\section{EXPERIMENTAL PART}

DME with a purity of $99.99 \%$ (manufactured by AkzoNobel Industrial Chemicals Specialty Chemicals, Netherlands) was used as a starting reagent.

In the reaction for obtaining lower olefins from DME, samples of HSZ zeolite catalysts with a $\mathrm{SiO}_{2} / \mathrm{Al}_{2} \mathrm{O}_{3}$ molar ratio of 26 and a content of no more than 0.07 wt. Active metals (Mg, Zn, Zr) were introduced by impregnating finished zeolite extruders at room temperature with an 
The American Journal of Applied Sciences

(ISSN - 2689-0992)

Published: November 21, 2020 | Pages: 34-43

Doi: https://doi.org/10.37547/tajas/Volumeo2Issue11-07

aqueous solution of a metal salt $\left(\mathrm{Al}_{2} \mathrm{O}_{3}\right)$, then dried and calcined at $500{ }^{\circ} \mathrm{C}$ for $4-6$ hours. The content of $\mathrm{Zn}$ and $\mathrm{Zr}$ in the finished catalyst is $0.1 \%, M g-1 \%$. The zeolites used for the preparation of the catalyst are a local analogue of the foreign zeolite of the chabazite type - the molar ratio of high-modulus zeolite (HSZ) $\mathrm{SiO}_{2} / \mathrm{Al}_{2} \mathrm{O}_{3}=26$ was synthesized in the scientific laboratory of Samarkand State University. The reaction was carried out in a flow-through quartz reactor, to which $0.3-1.0 \mathrm{~g}(0.6-2.0 \mathrm{ml})$ of a catalyst $0.2-1.6 \mathrm{~mm}$ in size was added. The required consumption of reagents (500-10000 $\left.\mathrm{h}^{-1}\right)$, temperature $\left(240-450{ }^{\circ} \mathrm{C}\right)$, and pressure ( $1 \mathrm{~atm}$.) Were established. The condensed liquid products were collected in a receiver, and the gas stream was fed to chromatographic analysis using a crusher (loop volume $1 \mathrm{ml}$ ). The reaction products were analyzed by gas chromatography. Quantumchemical calculations were performed using the density functional method B3LYP in the Gaussian-03 software package using the 6-31+ $G(d, p)$ base set, as well as the PRIRODA software in the PBE functional structure. To calculate the structures of the zeolite, a model with the MFI structure type with HSZ zeolite in the composition of the zeolite lattice was chosen (Fig. 1).

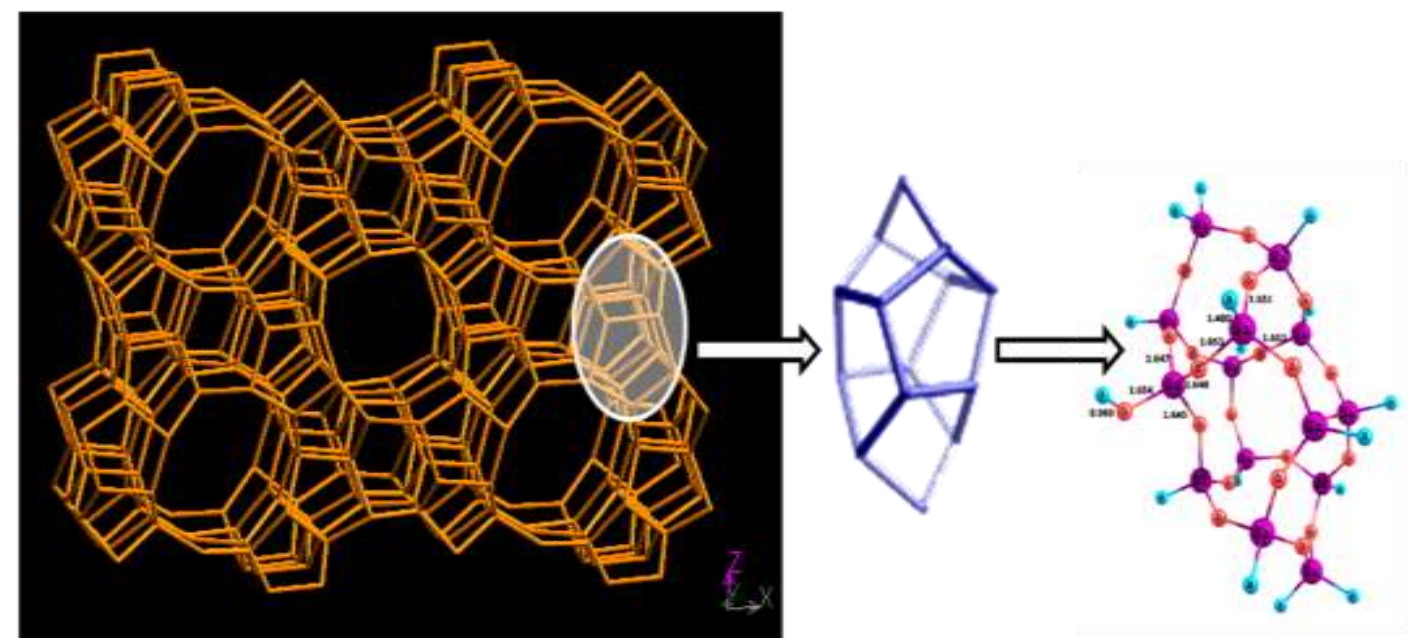

Figure 1. Selection of a zeolite structure model for calculations.

\section{RESULTS AND DISCUSSION}

The conversion of methanol to lower olefins was studied using Mg-Zn-Zr-B-HSZ and Mg-Zn$\mathrm{Zr}$-P-HSZ as catalysts. The overall yield of olefins $\mathrm{C}_{2}-\mathrm{C}_{4}$ (Fig. 2a) has a maximum value of $78 \%$, and its activity decreases to $10 \%$ after 3 hours of catalyst operation. Methane yield no more than $5 \%, \mathrm{C}_{5}+$ hydrocarbons no more than $3 \%$. As seen in Figure $2 b$, the ethylene yield in SAPO-34 increased slowly over the previous two hours, while the propylene yield decreased (Figure 2c).
After 3 hours of catalyst operation, its activity and selectivity drop sharply. The output of ethane and propane is about $10-12 \%$ of the total. The yield of butanes decreases with time (Fig. $2, \mathrm{~g})$, while the yield of butanes practically does not change and exceeds $2 \%$. 

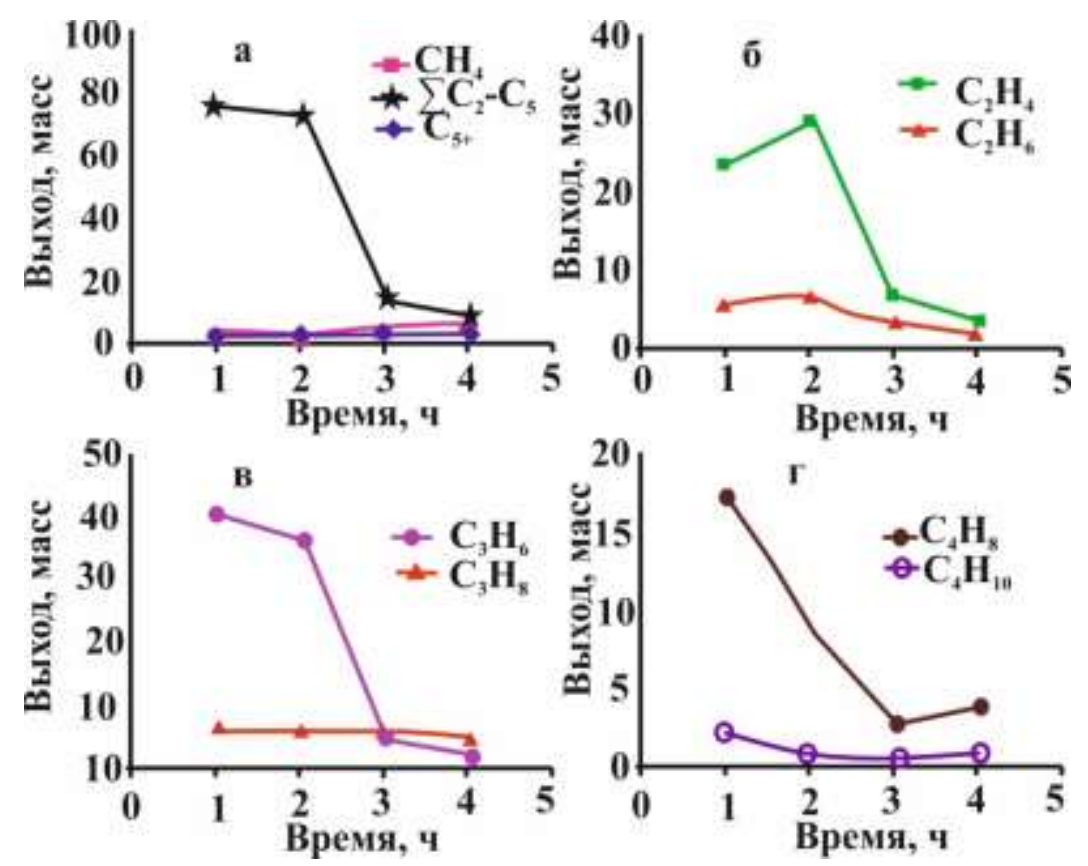

Figure 2. Dependence of the yield of reaction products on the catalyst operation time. $\left(V_{N_{2}}=2000 \mathrm{~h}^{-1}\right.$, $\mathrm{V}_{\text {Methanol }}=1 \mathrm{~h}, \mathrm{~T}=375^{\circ} \mathrm{C}, \mathrm{P}=0.1 \mathrm{MPa}$ )

When the temperature rises to $450^{\circ} \mathrm{C}$, there is an increase in methane production and a significant decrease in the yield of ethylene and propylene. However, when the $\mathrm{CH}_{3} \mathrm{OH}$ space velocity increases from $450{ }^{\circ} \mathrm{C}$ to $7 \mathrm{~h}-1$, a sharp increase in the ethylene yield is observed at the initial moment (Fig. 2), but after 30 minutes its yield begins to decrease. On the other hand, the propylene yield decreases under these conditions. To increase the stability of the SAPO-34 catalyst, it was modified with the metals $\mathrm{Zn}$ and Fe.

However, the modification with metals leads to a decrease in the yield of lower olefins. Thus, unmodified SAPO-34 is highly active (we observe high yields of lower olefins), but it is unstable. The decrease in the activity of the catalyst over time is due to the coking of the acid sites of the catalyst, which are responsible for the formation of olefins, and the clogging of the fine pores and channels of the zeolite.
HSZ based catalysts modified with boron or phosphorus compounds were tested for the conversion of DME dimethyl ether to olefins at 270 and $320^{\circ} \mathrm{C}$. As can be seen from Table 1 , the composition of the conversion and conversion products depends not only on the properties of the modifier metal but also on the temperature of the experiment (Table 1).

Since the target products of the investigated reactions are lower olefins, the determination of a sufficiently large amount of ethanol in the reaction products on the Mg-Zn-Zr-B-HSZ zeolite catalyst at $\mathrm{T}=270{ }^{\circ} \mathrm{C}$ is of interest for understanding the mechanism of olefin formation. The absence of alcohols in the reaction products $\mathrm{Mg}-\mathrm{Zn}-\mathrm{Zr}-\mathrm{P}-\mathrm{HSZ}$ under the same temperature conditions and with an increase in temperature in both catalysts to $320{ }^{\circ} \mathrm{C}$ Alcohols are intermediate products formed in sequentially or sequentially parallel reactions. indicates that this is possible. 
Table 1. Conversion of DME to olefins in the catalysts Mg-Zn-Zr-P-HSZ and Mg-Zn-Zr-B-HSZ.

\begin{tabular}{|c|c|c|c|c|c|c|c|c|}
\hline \multirow{2}{*}{ Catalyst } & \multirow{2}{*}{$\begin{array}{c}\text { DME } \\
\text { conversion, } \\
\%\end{array}$} & \multicolumn{6}{|c|}{ The composition of the reaction products, wt. $\%$} & \multirow[t]{2}{*}{$C_{2}=/ C_{3}=$} \\
\hline & & $\mathrm{CH}_{4}$ & $C_{2}=$ & $C_{3}=$ & $\sum C_{2}=-C_{4}=$ & $\sum \mathrm{C}_{2+}$ & $\mathrm{EtOH}$ & \\
\hline \multicolumn{9}{|c|}{$T=270^{\circ} \mathrm{C} ; P=0,1 \mathrm{MPa} ;$ initial mixture:10 vol.\% DME +90 vol. $\% \mathrm{~N}_{2}$} \\
\hline $\begin{array}{l}\text { Mg-Zn-Zr- } \\
\text { P-HSZ }\end{array}$ & 32.8 & 4.7 & 17.9 & 35.0 & 56.7 & 31.2 & 6.1 & 0.51 \\
\hline $\begin{array}{l}\text { Mg-Zn-Zr- } \\
\text { B- HSZ }\end{array}$ & 40.7 & 0.1 & 37.0 & 32.6 & 69.7 & 30.2 & - & 1.14 \\
\hline \multicolumn{9}{|c|}{$T=320^{\circ} \mathrm{C}\left(P=0,1 \mathrm{MPa}\right.$; initial mixture : $10 \mathrm{vol} . \% \mathrm{DME}+90 \mathrm{vol} . \% \mathrm{~N}_{2}$} \\
\hline $\begin{array}{l}\text { Mg-Zn-Zr- } \\
\text { P- HSZ }\end{array}$ & 87.4 & 0.4 & 28.2 & 35.4 & 75.2 & 24.4 & - & 0.80 \\
\hline $\begin{array}{c}\text { Mg-Zn-Zr- } \\
\text { B- HSZ }\end{array}$ & 87.5 & 0.1 & 38.5 & 34.7 & 76.7 & 23.2 & - & 1.11 \\
\hline
\end{tabular}

IR spectroscopy data showed a correlation with the results of catalytic experiments, as well as with differences in the relative composition of various reaction products in the system, as well as in the case of modified catalysts with different metals. Most of the characteristic ethanol bands $(3600,1045,1090$, $895 \mathrm{~cm}-1)$ are found only in the spectra of the Mg-Zn-Zr-P-HSZ surface at $140-200{ }^{\circ} \mathrm{C}$. In the spectrum of Mg-Zn-Zr-P-HSZ at a temperature of $120-180^{\circ} \mathrm{C}$ all bands characteristic of ketene (3055, 2080, $965 \mathrm{~cm}-1)$, and the spectra of MgZn-Zr-B-HSZ from $150{ }^{\circ} \mathrm{C}$ is observed at low temperatures. IRDO spectra of the surface of zeolite catalysts containing boron and phosphorus, preliminarily calcined at $400{ }^{\circ} \mathrm{C}$, were recorded in a DME stream at $320^{\circ} \mathrm{C}$; no traces of flax or ethanol were found. Moreover, under these temperature conditions, after 15 minutes of contact of DME with the surface, the adsorbed DME on the surface of the zeolite is not fixed and all lines that are characteristic only of olefins and alkanes appear. This paper presents the properties of the mechanism of conversion of
DME in phosphorus-modified zeolite catalysts, as well as experimental and theoretical methods of vibration spectroscopy, as well as quantum-chemical modelling at different temperatures $\left(120-320^{\circ} \mathrm{C}\right)$.

The mechanism of olefin formation from DME on the surface of zeolites at $120-200^{\circ} \mathrm{C}$.

Discussing the formation of ketol and its participation in the catalytic reaction, ketene is a very unstable molecule that readily decomposes to form carbyne and carbon monoxide (Scheme 1). In this case, strong Lewis acid sites (LAC) can be present in zeolite catalysts modified with phosphorus, the spectral properties of which are discussed in [1]. The hydrogenation ability of P-containing catalysts is well known; therefore, the hydrogenation of ketene to ethanol can occur on the surface of the Mg-Zn-Zr-P-HSZ: 
Scheme 1. Decomposition of ketol.
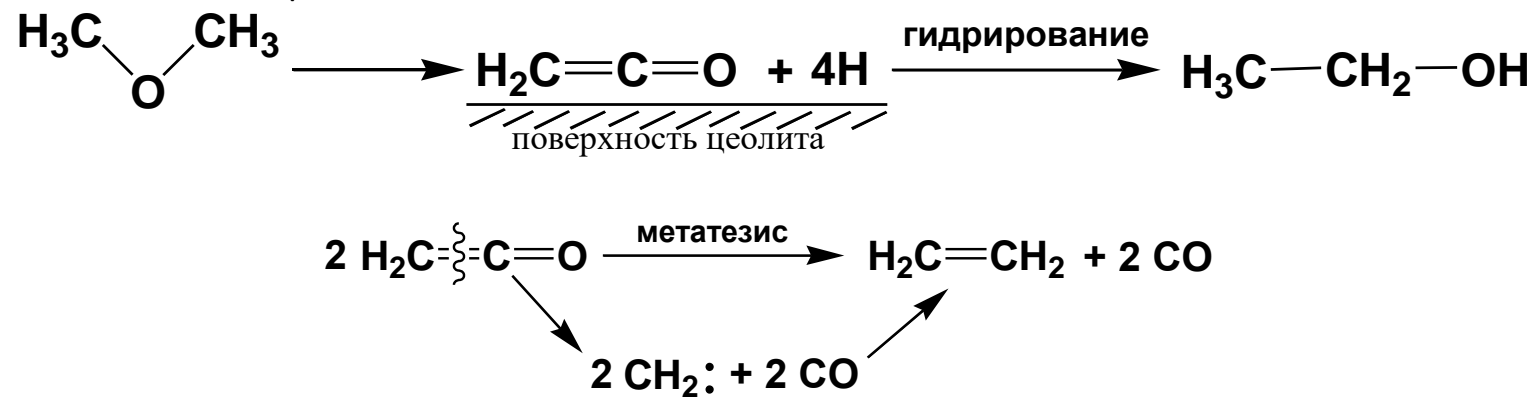

Further transformation of objects can go along the following paths:

- carbene polymerization

$$
\begin{aligned}
& n\left[: \mathrm{CH}_{2}\right] \mathbf{a}\left(\mathrm{CH}_{2}\right)_{\mathbf{n}} \\
& {\left[: \mathrm{CH}_{2}\right]+\mathrm{CH}_{3}-\mathrm{ORàCH}_{3} \mathrm{CH}_{2}-\mathrm{OR}} \\
& \mathrm{CH}_{3} \mathrm{CH}_{2}-\mathrm{ORàC}_{2} \mathbf{H}_{4}+\mathrm{HOR},
\end{aligned}
$$

where $R=H$ or alkyl.

To confirm the potential for the formation of flax and other products from DME, we calculated the energy balance of these substances:

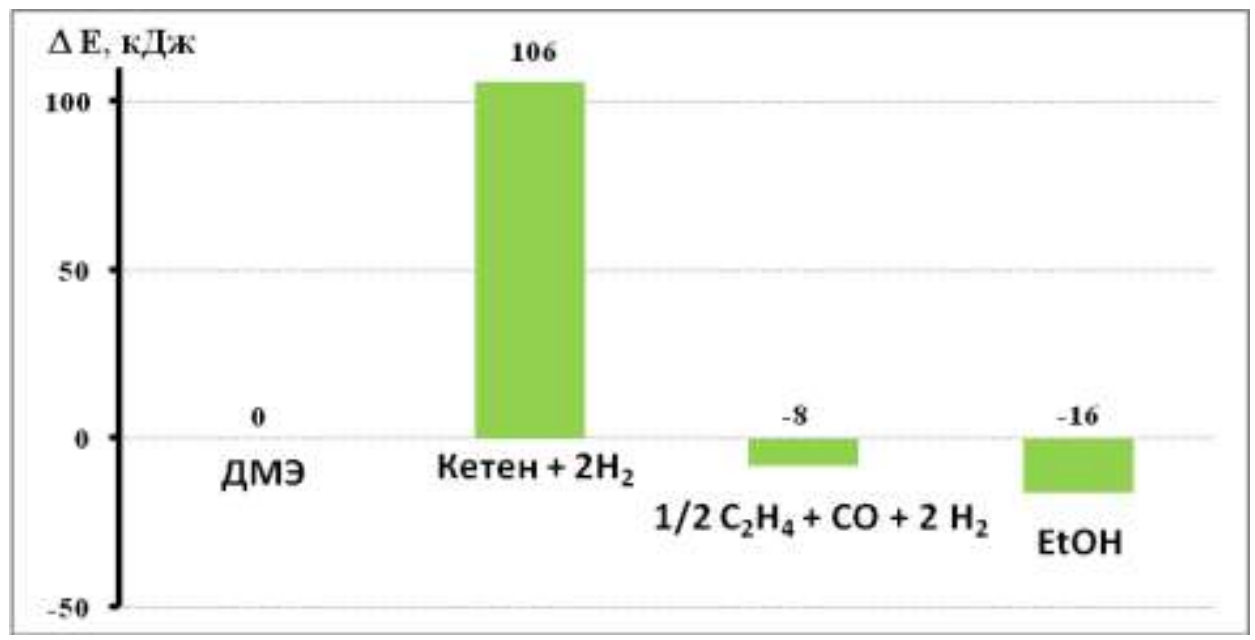

Figure: 3. Energy diagram of the conversion of DME through the formation of ketene.

As can be seen from the diagram, the energies of the $106 \mathrm{~kJ} / \mathrm{mol}$ intermediate compounds are low enough for such reactions to occur at sufficiently low temperatures. Thus, according to in situ IR spectroscopy data, at temperatures below $200{ }^{\circ} \mathrm{C}$, the carbenium mechanism to form the primary $\mathrm{C}-\mathrm{C}$ bond can be realized [20-24].
The mechanism of formation of olefin from DME on the surface of zeolites at $320{ }^{\circ} \mathrm{C}$. Analysis of the spectra at temperatures above $300{ }^{\circ} \mathrm{C}$ showed that the composition of the products differed significantly from those recorded at temperatures below $200^{\circ} \mathrm{C}$ (Figure 4). 


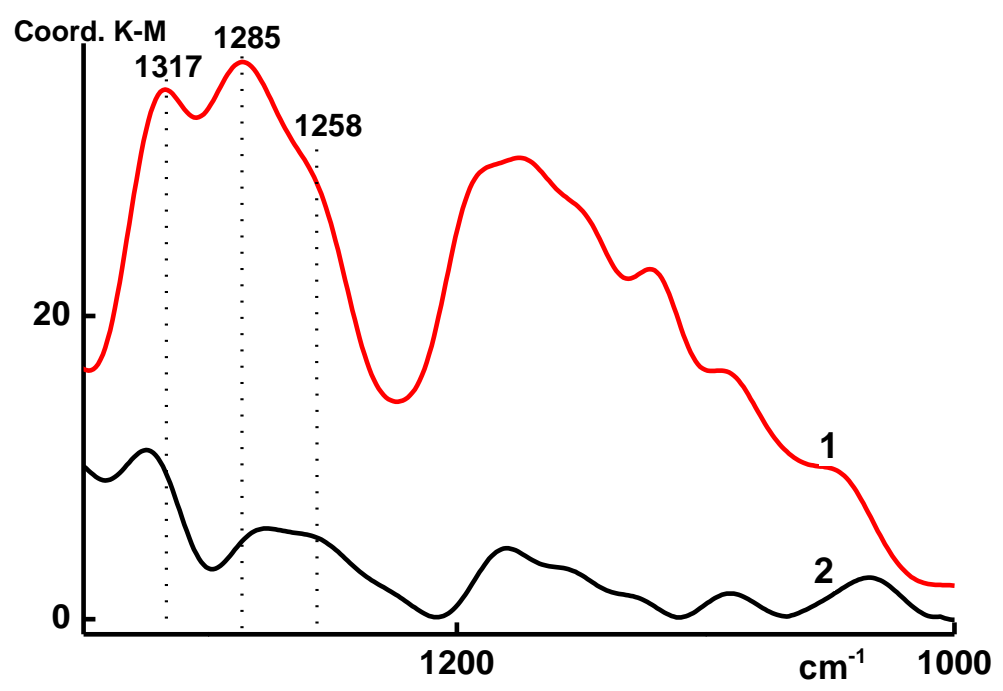

Figure: 4. Comparison of the differential spectra of IR LEDS of the surface of the catalyst Mg-Zn-Zr-BHSZ in a current of DME at a temperature of $320^{\circ} \mathrm{C}$ after 5 (1) and 100 (2) minutes of interaction.

In the spectrum of the Mg-Zn-Zr-B-HSZ surface, significant differences are observed in the region of $1100-1300 \mathrm{~cm}-1$ (Fig. 4), depending on the temperature at which the spectrum is recorded. At temperatures above $200{ }^{\circ} \mathrm{C}$, very dense bands are observed in the $1200-1300 \mathrm{~cm}$ 1 range. The high intensity of these bands indicates that they belong to $\mathrm{C}$ - $\mathrm{O}$ compounds, but their attachment to the adsorbed DME on the surface is inappropriate since the $\mathrm{C}$ - $\mathrm{O}$ bonds inside the DME are characterized by lines below $1180 \mathrm{~cm}-1$.

Therefore, it can be assumed that these bands are related to intermediate products of ozone, which arise as a result of the conversion of
DME. Calculations of models of intermediates $\left(\mathrm{CH}_{3}\right)_{3} \mathrm{O}+$ and $\left(\mathrm{CH}_{3}\right)_{2} 2 \mathrm{O}+\mathrm{CH}_{2}$ - associated with active centres of zeolite (Fig. 4) showed extended vibration frequencies of $\mathrm{C}$ - $\mathrm{O}$ bonds. Compounds move to the region of 1250-1280 $\mathrm{cm}-1$.

That is, the theoretical frequencies of ozone intermediates, adapted to the surface of the zeolite, are in good agreement with the experimental data of high-temperature IR in situ studies. It can be assumed that at high temperatures in the IRDO spectra it is possible to determine the intermediate products of the reaction of DME with olefins and to confirm the mechanism of oxidation of this reaction. 


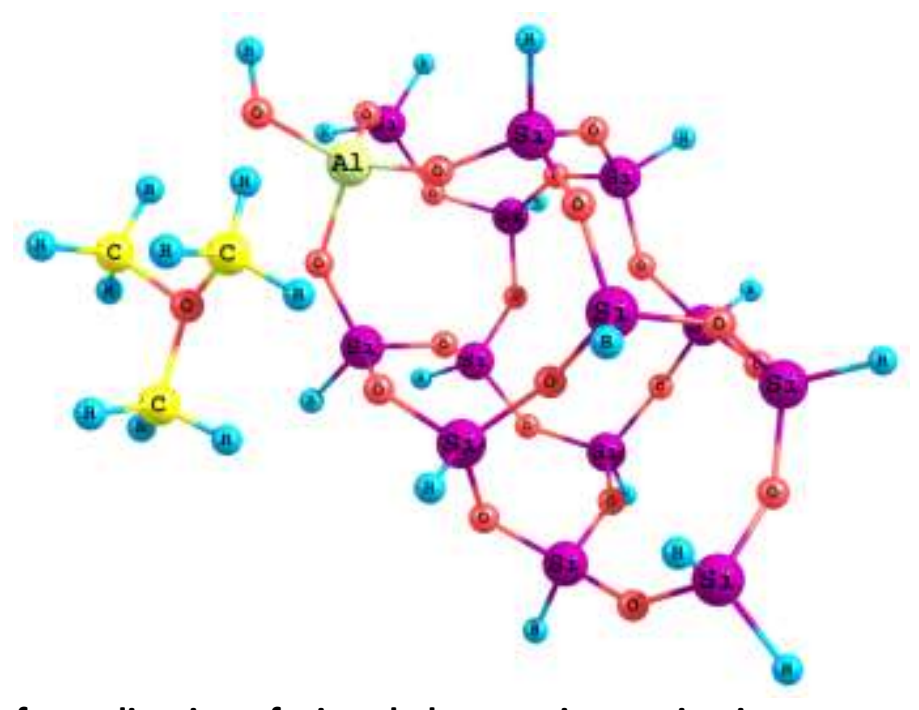

Figure 5. Model of coordination of trimethylammonium cation in a structural cell of zeolite.

\section{CONCLUSION}

On the surface of catalysts based on HSZ zeolite modified with boron and phosphorus, high-temperature FT-IR spectroscopy DR revealed intermediate compounds during the conversion of DME on them: ketones at temperatures below $180{ }^{\circ} \mathrm{C}$ and oxane intermediates at $320^{\circ} \mathrm{C}$. Theoretical quantumchemical calculations of such models of intermediates are in good agreement with experimental spectra. The formation of olefins from DME can occur by two mechanisms that are not completely related to each other, depending on the temperature: at low temperatures by the carbenium mechanism and high temperatures by the oxidative sludge mechanism.

\section{REFERENCES}

1. Fayzullayev. N.I. (2015). Catalytic Oxicondensation of Methane. International Journal of Chemical and Physical Science. 4(2). 49-54.

2. Rakhmatov, S. B., \& Fayzullayev, N. I. (2020). Coke Formation of Catalyst on the Ethylene Preparation from the
Oxycondensation of Methane and its Regeneration. International Journal of Advanced Science and Technology, 29(03), 7875-7884.

3. Tursunova, N. S., \& Fayzullaev, N. I. (2020). Kinetics of the Reaction of Oxidative Dimerization of Methane. International Journal of Control and Automation, 13(2), 440-446.

4. Fayzullaev, N. I., \& Tursunova, N. S. (2020). Thermodynamic Basis of Methane Oxidation Dimerization Reaction and Process Approval. International Journal of Advanced Science and Technology, 29(5), 65226531.

5. Fayzullaev, N. I., \& Raxmatov, S. B. (2020). Kinetics and Mechanisms of Oxycondensation Reaction in Methane Molybden-Marganets-Zirconium

Catalysis. International Journal of Psychosocial Rehabilitation, 24(04).

6. Omanov, B. S., Fayzullayev, N. I., \& Xatamova, M. S. (2019). Vinyl acetate Production out of acetylene. International Journal of Advanced 
Research in Science, Engineering and Technology, 6(12).

7. Omanov, B. S., Fayzullayev, N. I., \& Xatamova, M. S. (2020). Catalytic synthesis of acetylene ut of vynil acetate and texture characteristics of catalysts. Asian Journal of Multidimensional Research (AJMR). Special Issue, March, 157-164.

8. Mamadoliev, I. I., \& Fayzullaev, N. I. (2020). Optimization of the Activation Conditions of High Silicon Zeolite. International Journal of Advanced Science and Technology, 29(03), 68076813.

9. Ibodullayevich, F. N., Yunusovna, B. S., \& Anvarovna, X. D. (2020). Physicochemical and texture characteristics of Zn-Zr/VKTS catalyst. Journal of Critical Reviews, 7(7), 917-920.

10. Fayzullaev, N. I., Akmalaev, K. A., Karjavov, A., Akbarov, H. I., \& Qobilov, E. (2020). Catalytic Synthesis Of Acetone And Acetaldehyde From Acetylene In Fluoride-Based Catalysts. The American Journal of Interdisciplinary Innovations and Research, 2(09), 89-100.

11. Fayzullaev, N. I., Jumanazarov, R. B., \& Turabjanov, S. M. (2015). Heterogeneous Catalytic Synthesis of Vinylchloride by Hydrochlorination of Acetylene. IJISET-International Journal of Innovative Science, Engineering \& Technology, 2(9).

12. Akmalaiuly, K., Ibodullaevich, F. N., \& Rahmonovich, K. A. (2020). Joint Synthesis of Acetone And Acetaldehyde From Acetylene. The American Journal of Engineering and Technology, 2(09), 109-119.

13. Fayzullayev, N. I. (2019). Kinetics and mechanism of the reaction of the catalytic oxycondensation reaction of methane. Austrian Journal of Technical and Natural Sciences, (5-6).

14. Treger, Y. A., \& Rozanov, V. N. (2016). Technologies for the synthesis of ethylene and propylene from natural gas. Review Journal of Chemistry, 6(1), 83-123.

15. Chang, C. D., \& Silvestri, A. J. (1977). The conversion of methanol and other $\mathrm{O}$ compounds to hydrocarbons over zeolite catalysts. Journal of catalysis, 47(2), 249-259.

16. Bjørgen, M., Joensen, F., Lillerud, K. P., Olsbye, U., \& Svelle, S. (2009). The mechanisms of ethene and propene formation from methanol over high silica H-ZSM-5 and H-beta. Catalysis Today, 142(1-2), 90-97.

17. Jean, L. (2005). Effect of process parameters on methanol to olefins reactions over SAPO catalysts, (Doctoral dissertation).

18. Guisnet, M., \& Gilson, J. P. (Eds.). (2002). Zeolites for cleaner technologies, (Vol. 3). London: Imperial College Press.

19. Cai, G., Liu, Z., Shi, R., Changqing, H., Yang, L., Sun, C., \& Chang, Y. (1995). Light alkenes from syngas via dimethyl ether. Applied Catalysis A: General, 125(1), 29-38.

20. Sun, J., Yang, G., Yoneyama, Y., \& Tsubaki, N. (2014). Catalysis chemistry of dimethyl ether synthesis. ACS Catalysis, 4(10), 3346-3356.

21. Bobomurodova, S. Y., Fayzullaev, N. I., \& Usmanova, K. A. (2020). Catalytic Aromatization of Oil Satellite Gases. International Journal of Advanced Science and Technology, 29(5), 30313039.

22. Fayzullaev, N. I., Saginaev, A. T., Shukurov, B. S., \& Holliyev, S. K. Catalytic dehydroaromatization oil associated gas. С. Өтебаев Атындағы Атырау Мұнай Және Газ Университетінің Хабаршысы, 27.

23. Fayzullayev, N., Akmalaiuly, K., \& Karjavov, A. (2020). Catalytic synthesis of a line by acetylene hydration. News of the National Academy of Sciences of the Republic of Kazakhstan, Series 
chemistry and technology, 2(440), 23-

30.

24. Kolesnichenko, N. V., Goryainova, T. I., Biryukova, E. N., Yashina, O. V., \& Khadzhiev, S. N. (2011). Synthesis of lower olefins from dimethyl ether in the presence of zeolite catalysts modified with rhodium compounds. Petroleum Chemistry, 51(1), 55-60. 